\title{
An incidental finding of an oesophageal duplication cyst
}

\author{
Avinash Aujayeb, ${ }^{\odot}$ Parag Narkhede
}

Northumbria Healthcare NHS Foundation Trust, North Shields, UK

Correspondence to Dr Avinash Aujayeb, avinash.aujayeb@nhct.nhs.uk

$\mathrm{AA}$ and $\mathrm{PN}$ contributed equally.

Accepted 3 August 2019

\section{DESCRIPTION}

A 37-year-old male patient was referred to with progressive breathlessness, intermittent and a troublesome nighttime cough. He was a never smoker. He had asthma until his early teenage years and had since been asymptomatic. He was on inhaled longacting bronchodilators and steroids.

A chest radiograph (figure 1) showed left perihilar consolidation. He was started on inhaled dual bronchodilators and steroids. A short course of antibiotics enabled clearance of his radiograph (figure 2). Symptoms improved initially, but recurring symptoms of cough and sputum expectoration prompted a CT as part of the diagnostic workup for potential bronchiectasis.

Figures 3 and 4 show slices of the CT. There is minor bronchial wall thickening but no features of bronchiectasis. There is a lobulated posterior mediastinal mass (attenuation value 50 Hounsfield units) in the lower thorax separate from aorta and in loose contact with the oesophagus. The chest radiographs were retrospectively reviewed, and this lesion can be clearly seen behind the left heart border. Thoracic MRI was undertaken. The lesion is seen in the posterior mediastinum in the left paravertebral recess, measuring $7.3 \times 6.2 \mathrm{~cm}$ on sagittal images. The lesion shows high signal intensity on T2-weighted images (figure 5) and low intensity on the T1-weighted image (figure 6). There is no evidence of spinal or oesophageal communication.

The regional cardiothoracic multidisciplinary meeting felt that this was an oesophageal duplication cyst. An endoscopy showed a small hiatus hernia, no abnormality or indentation or communication seen in the oesophagus. There was some

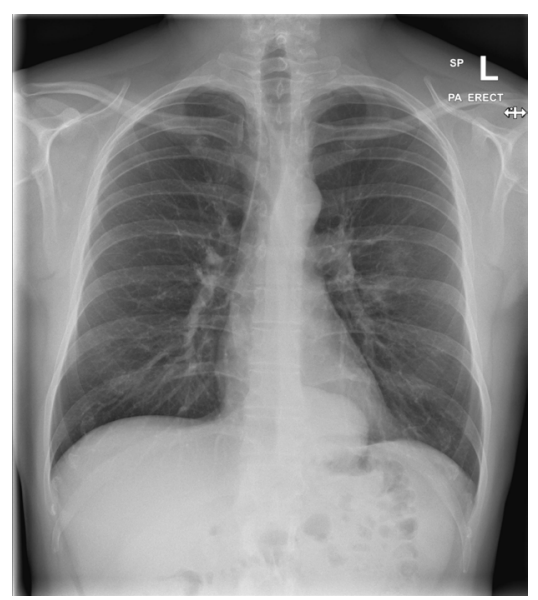

Figure 1 Chest radiograph showing left perihilar consolidation.

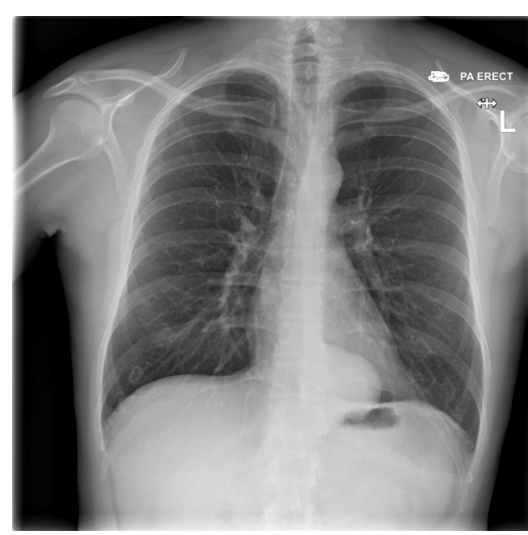

Figure 2 Chest radiograph showing clearance of left perihilar consolidation.

oesophageal candidiasis, probably due to his inhaled steroids. Endoscopic ultrasound was not performed as it is not locally available.

Gastrointestinal tract duplication cysts are rare congenital malformations. They originate from the foregut, the small and large bowel. ${ }^{12}$ Oesophageal cysts arise from abnormal budding of the embryonic foregut between approximately 3 and 8 weeks' gestation. They are the second most common type of cysts following small bowel ones. They account for approximately $15 \%$ of duplication cysts, are rare with an overall estimated prevalence of $0.0122 \%$ and over two-thirds arise from the lower third of the oesophagus into the right inferior and posterior mediastinum, with no intraluminal communication. $^{12}$

CT typically shows well-defined thick-walled structures along the oesophagus. MRI T1 images show low-to-intermediate signal intensity, and T2 images show high signal intensity. Different timings

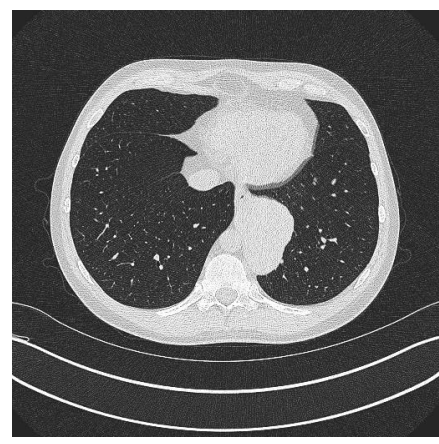

Figure 3 CT image (lung window) showing minor bronchial wall thickening and lobulated posterior mediastinal mass. 


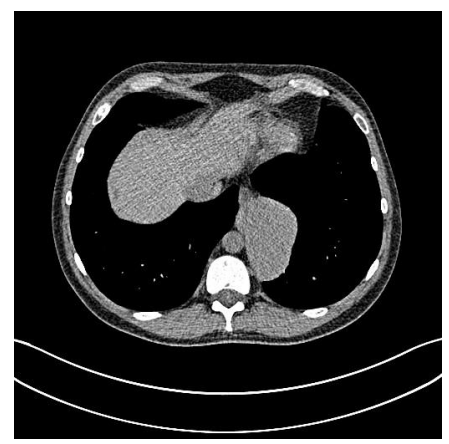

Figure 4 CT image (mediastinal window) showing lobulated posterior mediastinal mass in the lower thorax, separate from aorta and in loose contact with the oesophagus.

of the radiofrequency pulses make T1 images highlight fat tissue and T2 images highlight fat and water. ${ }^{1}$

The differential diagnoses for complicated cysts (those that have debris inside) are abscesses, enlarged necrotic lymph nodes, pulmonary masses and congenital cystic adenomatoid malformation. Differential diagnoses for uncomplicated cysts include pericardial cysts, cystic hygromas or lymphangiomas, neurenteric cysts, anterior or lateral meningoceles, thymic cysts or pancreatic pseudocysts. ${ }^{1}$

The cysts are commonly asymptomatic and picked up incidentally. However, cysts located in the upper oesophagus can cause cough, while cysts lower down can cause dysphagia, epigastric discomfort, chest pain and vomiting. Cardiac arrhythmias, chest

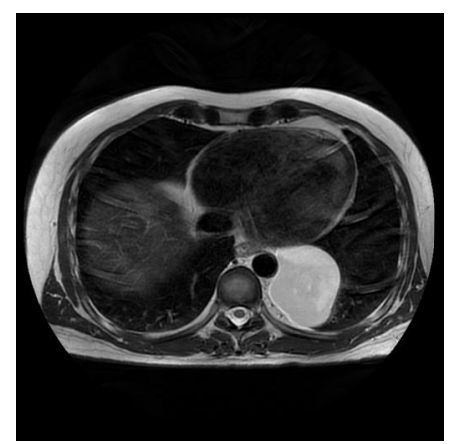

Figure 5 MRI with lesion showing high signal intensity on T2weighted slices.

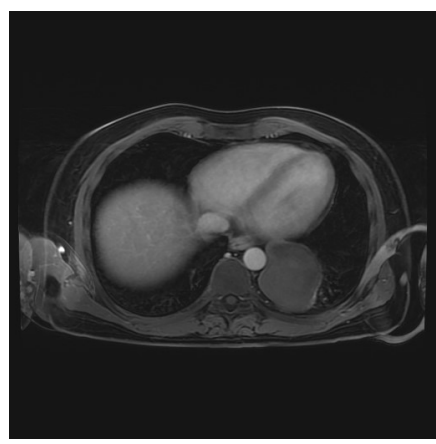

Figure 6 MRI with lesion showing low signal intensity on T1weighted slices.

pain, ulceration and bleeding and cyst rupture have all been described. ${ }^{12}$

Surgical resection is then the treatment of choice. The vast majority, which cause no symptoms, are simply observed. ${ }^{12}$

Our patient fits into this classic picture: incidental discovery, presence in the lower third of the oesophagus and no communication with the oesophageal lumen. He continues under observation.

\section{Learning points}

- Oesophageal duplication cysts are rare congenital malformations from the gastrointestinal tract.

- They are normally picked up incidentally.

- They usually do not require treatment unless compressive symptoms arise.

Contributors AA and PN both wrote the initial manuscript and both corrected it.

Funding The authors have not declared a specific grant for this research from any funding agency in the public, commercial or not-for-profit sectors.

Competing interests None declared.

Patient consent for publication Obtained.

Provenance and peer review Not commissioned; externally peer reviewed.

\section{REFERENCES}

1 Wild D, Guelrud M. Benign lesions of the esophagus. https://www.uptodate.com/ contents/benign-lesions-of-the-esophagus (26 May 2019).

2 Liu R, Adler DG. Duplication cysts: diagnosis, management, and the role of endoscopic ultrasound. Endosc Ultrasound 2014;3:152-60.

Copyright 2019 BMJ Publishing Group. All rights reserved. For permission to reuse any of this content visit

https://www.bmj.com/company/products-services/rights-and-licensing/permissions/

BMJ Case Report Fellows may re-use this article for personal use and teaching without any further permission.

Become a Fellow of BMJ Case Reports today and you can:

- Submit as many cases as you like

- Enjoy fast sympathetic peer review and rapid publication of accepted articles

- Access all the published articles

- Re-use any of the published material for personal use and teaching without further permission

Customer Service

If you have any further queries about your subscription, please contact our customer services team on +44 (0) 2071111105 or via email at support@bmj.com.

Visit casereports.bmj.com for more articles like this and to become a Fellow 